\title{
WACANA NEGARA MARITIM \\ DAN REIMAJINASI NASIONALISME INDONESIA
}

\author{
Caroline Paskarina \\ Departemen Ilmu Politik FISIPUniversitas Padjadjaran \\ E-mail: caroline.paskarina@unpad.ac.id
}

\begin{abstract}
Although Indonesia is an archipelagic state, but the discourse on maritime state is not yet become the main discourse in the construction of nation and state of Indonesia. This discourse is re-emerged when President Joko Widodo make it as one of the main strategic agenda of his administration. The re-emerging of this maritime nation discourse is interesting to be studied in terms of nationalism, as an attempt to reconstructing the Indonesian national identity imagination. By tracking the dynamics of the arguments that enliven the discourse in Indonesian politics, this paper wants to uncover why this discourse re-emerged and what is the political interests behind the reimagination of Indonesian nationalism.
\end{abstract}

Keywords: maritime state, reimagination of identity, nationalism

\begin{abstract}
ABSTRAK
Kendati Indonesia merupakan negara kepulauan, tapi wacana tentang negara maritim bukan wacana utama dalam konstruksi kebangsaan dan kenegaraan Indonesia. Wacana ini baru muncul kembali ketika Presiden Joko Widodo menjadikannya sebagai salahsatu agenda strategis dalam pemerintahannya. Kemunculan kembali wacana negara maritim ini menarik untuk dikaji dari sisi nasionalisme, sebagai sebuah upaya untuk membentuk kembali imajinasi identitas kebangsaan Indonesia.Dengan melacak dinamika argumentasi yang mewarnai perjalanan wacana negara maritim dalam politik Indonesia, tulisan ini ingin mengungkap mengapa wacana negara maritim muncul dan kepentingan di balik reimajinasi nasionalisme Indonesia tersebut.
\end{abstract}

Kata kunci: negara maritim, reimajinasi identitas, nasionalisme

\section{PENDAHULUAN}

JanjiyangdiucapkanPresidenJokoWidodo untuk menjadikan Indonesia sebagai negara maritim memicu kembalinya wacana ini dalam agenda politik Negara Indonesia. Perdebatan yang kemudian menyertainya segera muncul, seperti apakah janji itu realistik, mengingat telah sekian lama negara ini bergantung pada sistem transportasi darat. Kalaupun secara geografis Indonesia adalah negara kepulauan, tetapi keberadaan laut lebih banyak dianggap sebagai penghambat mobilitas, sehingga kebijakan yang dibuat cenderung berpihak pada transportasi berbasis daratan, antara lain dengan membangun jembatan yang menghubungkan antarpulau. Bayangan tentang negara maritim mungkin hanya akan menjadi ingatan sejarah yang dipelajari ketika masa sekolah, di mana kerajaan-kerajaan besar di Nusantara dituliskan dalam buku sejarah sebagai kerajaan maritim yang gagah perkasa. Kejayaan nenek moyang bangsa Indonesia sebagai bangsa pelaut pun diceritakan turun-temurun melalui buku-buku sejarah, peninggalan sejarah, bahkan lagu anakanak. Tetapi, seperti apa sebenarnya negara maritim tidak berkembang menjadi perdebatan, apalagi agenda kebijakan. Imajinasi negara maritim tampaknya terhenti sebagai bagian dari kejayaan masa lampau Indonesia. Cerita tentang kejayaan negara maritim yang sarat dengan romantisme ini tidak pelak menjadi instrumen yang ampuh untuk membentuk rasa kebangsaan dan kebanggaan sebagai bangsa yang mewarisi sejarah peradaban.

Kembalinya wacana negara maritim yang diinisiasi oleh Presiden Joko Widodo menarik untuk dikaji dari sisi nasionalisme, sebagai sebuah upaya untuk membentuk kembali imajinasi identitas kebangsaan Indonesia. Dengan melacak dinamika argumentasi yang mewarnaiperjalanan wacana negara maritim dalam politik Indonesia, 
tulisan ini ingin mengungkap mengapa wacana negara maritim muncul dan kepentingan di balik reimajinasi nasionalisme Indonesia tersebut.

Pembicaraan tentang nasionalisme di Indonesia tidak dapat dilepaskan dari heroisme sejarah perlawanan untuk meraih kemerdekaan. Dalam konteks tersebut, nasionalisme diartikan sebagai paham yang mempersatukan berbagai suku bangsa di Indonesia untuk bersama-sama melawan kolonialisme. Kesamaan tujuan untuk menjadi bangsa yang merdeka inilah yang kemudian mendasari pergerakan rakyat saat itu untuk melawan penjajahan. Makna heroik ini yang kemudian dipakai untuk membangun rasa kebersamaan yang bersifat lintas etnis dan melampaui ikatan-ikatan primordial. Bahkan setelah Indonesia merdeka, pemahaman tentang nasionalisme selalu dikaitkan dengan entitas kenasional-an, yang merupakan penggabungan dari ragam identitas lokal atas nama persatuan dan kesatuan. Nasionalisme untuk kepentingan melawan penjajahan, dibentuk sebagai instrumen pemersatu bangsa. Sentimen nasionalisme, karena itu, senantiasa dihasilkan dari mobilisasi perasaan atau imajinasi masyarakat sebagai entitas yang berbeda dengan entitas lain yang dibentuk sebagai musuh bersama yang harus dilawan. Rasa persatuan dibentuk dengan dasar argumen kesamaan latarbelakang historis dan kebersamaan dalam menjalani perjalanan historis tersebut. Seperti halnya dalam perjuangan melawan penjajah, nasionalisme dilekatkan dengan jargon 'senasib sepenanggungan', demikian pula setelah kemerdekaan, nasionalisme adalah 'persatuan dan kesatuan'.

Dengan demikian, nasionalisme merupakan konstruksi sosial yang dilakukan untuk kepentingan tertentu. Ketika pembangunan nasionalisme tersebut dilakukan oleh negara, maka nasionalisme menjadi basis legitimasi untuk membangun loyalitas terhadap negara. Pada masa perjuangan melawan penjajah, nasionalisme dibangun di atas tujuan bersama untuk meraih kemerdekaan, sehingga kendati ada beragam ideologi yang berkembang saat itu tapi loyalitasnya tetap pada tujuan bersama tersebut. Demikian pula, pada masa setelah kemerdekaan, nasionalisme direkonstruksi dengan makna baru yang tujuannya tetap memberikan legitimasi terhadap kepentingan negara. Masa Orde Lama di bawah kepemimpinan Soekarno mengemas nasionalisme sebagai dasar bagi revolusi mela- wan kekuatan-kekuatan neokolonialisme dan neoimperialisme, sedangkan masa Orde Baru di bawah kepemimpinan Suharto mengaitkan nasionalisme dengan pembangunan. Nasionalisme pada masa Orde Baru adalah ketika bangsa Indonesia patuh pada ideologi pembangunan dan berpartisipasi dalam pembangunan. Pemaknaan ini direproduksi oleh negara melalui institusiinstitusi pendidikan, organisasi kemasyarakatan, dan partai politik, serta organisasi komunitas di level grass root seperti RT, RW, Karang Taruna, Dharma Wanita, yang semuanya mengarahkan pembentukan identitas nasionalisme sebagai identitas dari orang-orang yang berpartisipasi dalam pembangunan.

Transisi dari masa Orde Baru memunculkan konstruksi nasionalisme yang berbeda lagi. Sentralisasi yang demikian kuat pada masa Orde Baru memunculkan perasaan-perasaan ketertindasan dari daerah-daerah dan etnisitas yang berada di luar Jawa, sehingga ketika Orde Baru berakhir, seolah-olah memberi peluang menguatnya identitas lokal yang sempat termarginalkan. Nasionalisme pada masa ini justru menghadapi perlawanan dari daerahdaerah yang menginginkan identitasnya diakui. Pasang-surut nasionalisme pada masa reformasi ini tidak dapat secara otomatis diartikan sebagai disintegrasi, tapi lebih sebagai cerminan dari ketidakpuasan dan delegitimasi negara. Seperti juga nasionalisme dipakai sebagai instrumen oleh negara untuk membangun loyalitas dan legitimasi, demikian pula kegagalan dalam mengurus negara akan menjadi penyebab melemahnya nasionalisme (Santoso, 2001).

Kondisi ini berubah ketika pemerintahan Jokowi membangkitkan kembali ide tentang nasionalisme yang dibangun dari kedaulatan di laut. Pada masa kejayaan kerajaan-kerajaan di Nusantara, kedaulatan laut menjadi salahsatu kebanggaan bahkan identitas dari banyak kerajaan besar Nusantara, seperti Sriwijaya dan Majapahit. Tapi identitas sebagai bangsa bahari ini seolah-olah lenyap karena selama rentang panjang masa awal kemerdekaan hingga sekarang, nasionalisme yang dibangun adalah nasionalisme yang berbasis daratan. Kendati Indonesia adalah negara kepulauan, tapi sentralisasi sumber daya menyebabkan pembangunan hanya berlangsung di pulaupulau besar yang tidak saling terkoneksi dengan baik, seolah-olah masing-masing 
pulau mengejar pertumbuhan ekonominya sendiri. Pusat-pusat pertumbuhan ekonomi tetap berbasis pada pengembangan potensi daratan bukan pergerakan sumber daya melalui laut di antara pulau-pulau tersebut. Ini adalah konsekuensi dari ideologi pembangunan yang orientasinya pertumbuhan ekonomi. Pertumbuhan ekonomi hanya bisa dicapai dengan cepat melalui akumulasi kapital. Kapital akan berputar dengan cepat jika ada produktivitas dan industrialisasi menjadi strategi utama untuk menciptakan produktivitas ini. Industrialisasi untuk menciptakan produktivitas yang tinggi akan bisa dicapai melalui transportasi darat dan udara. Karena itu tidak ada kepentingan untuk mengembangkan nasionalisme berbasis maritim. Laut bahkan kemudian dipandang sebagai penghalang, sehingga strategi pembangunan infrastruktur yang marak diterapkan saat itu adalah membangun sebanyak mungkin jembatan, bukan mendayagunakan pelabuhanpelabuhan yang tersedia.

Pemerintahan Jokowi menawarkan perubahan cara pandang dari nasionalisme daratan menjadi nasionalisme maritim. Indonesia jelas adalah negara kepulauan, laut seharusnya menjadi sumber kekuatan yang sangat strategis. Tidak hanya untuk perputaran sumber daya, juga untuk pertahanan. Simbol kedaulatan terbesar yang seharusnya dimiliki Indonesia adalah kedaulatan di laut karena Indonesiaadalahnegara kepulauan. Cara pandang inilah yang kemudian dipakai Jokowi untuk membangkitkan kembali nasionalisme maritim. Langkah pertama yang dilakukan adalah mengembalikan kepercayaan publik bahwa Indonesia punya kedaulatan di laut. Upaya ini misalnya, dilakukan oleh Menteri Kelautan dan Perikanan untuk menunjukkan bahwa Indonesia punya keberanian untuk melawan para pelaku illegal fishing. Tapi, ini tidak cukup untuk menguatkan nasionalisme maritim. Nasionalisme adalah rekayasa politik, sehingga reimajinasi tentang identitas bangsa perlu dibangun melalui perubahan sistematis dalam mengelola laut, diawali dari membentuk kembali cara pandang masyarakat terhadap laut hingga merumuskan desain kebijakan yang jelas mengenai pengelolaan laut.

\section{PASANG SURUT IDENTITAS BAHARI}

Nasionalisme bukanlah sesuatu yang alamiah dan statis, melainkan dibentuk dan dinamis. Dalam perjalanan sejarah, nasio- nalisme Indonesia adalah nilai-nilai yang dibentuk untuk melawan dominasi kolonialisme oleh sekelompok masyarakat yang sebelumnya memiliki identitas masing-masing yang terpisah. Sebagai sebuah identitas kebangsaan, Indonesia baru terbentuk pada awal abad ke-20, ketika ada kesepakatan untuk mendeklarasikan identitas baru yang melampaui identitas berbasis etnis yang sebelumnya digunakan. Identitas sebagai bangsa Indonesia ini kemudian mencapai puncaknya ketika Indonesia diproklamasikan sebagai negara yang merdeka.

Kahin (1952) menggunakan beragam perspektif untuk menjelaskan bangkitnya nasionalisme Indonesia, antara lain ekonomi politik runtuhnya (kekuasaan) kolonial; perubahan-perubahan sosio-psikologis dan distorsi hubungan sosial yang ditimbulkan oleh kolonialisme; tumbuhnya kesadaran politik nasional akibat kebijakan pendidikan kolonial Belanda yang ditujukan kepada golongan penduduk pribumi tertentu Hindia Belanda. Akan tetapi, dalam mencari asal usul nasionalisme Indonesia, Kahinjugamengajukan adanya faktor lain dari timbulnya nasionalisme tersebut, yakni batas-batas teritorial Hindia Timur Belanda yang secara kasar bersesuaian dengan teritori dua kerajaan besar 'Indonesia' dari abad ke-9 dan ke-15, yakni Sriwijaya dan Majapahit (dalam Philpott, 2001).

Asumsi Kahin tersebut memberikan nilai penting pada aspek ruang dalam perkembangan kesadaran nasional Indonesia. Sriwijaya dan Majapahit muncul sebagai hasil penaklukan oleh para penduduk Jawa, sementara Hindia Belanda muncul sebagai hasil penaklukan Jawa dan bagian-bagian 'Indonesia' lainnya oleh Belanda (Philpott, 2001). Perbedaan ini menunjukkan bahwa penentu identitas kebangsaan bukanlah pengaturan persoalan sosial, melainkan ruang atau wilayah yang menjadi batas-batas Hindia Belanda, Sriwijaya, dan Majapahit. Deskripsi tentang Kerajaan Sriwijaya dan Majapahit yang kemudian seringkali dipakai untuk membangun kebanggaan sebagai pewaris dari kejayaan kerajaan-kerajaan tersebut lebih merupakan upaya untuk menunjukkan bahwa negara Indonesia memiliki hubungan yang linier dan kontinyu dengan masyarakat-masyarakat sebelumnya dan 'bangsa Indonesia'adalah identitas yang inheren dalam sejarah, yang dibawa ke permukaan oleh kemunculan sebuah negara baru (Kahin dalam Philpott, 2001). 
Merujuk pada pendapat Kahin di atas, dimensi ruang memang berperan penting dalam pembentukan identitas kebangsaan tapi ternyata kejayaan Sriwijaya dan Majapahit tidak serta merta membentuk identitas bangsa Indonesia sebagai bangsa bahari. Keterputusan ini diakibatkan oleh pertarungan ekonomi politik antara Timur dan Barat yang berlangsung dalam abad ke-15 sampai ke-17 di wilayah laut Asia Tenggara (Reid, 2004). Posisi strategis wilayah laut di Asia Tenggara membuat interaksi Timur dan Barat berlangsung sangat dinamis di kawasan ini. Kenneth R. Hall (1985) bahkan menyatakan bahwa sudah terbentuk pusat-pusat kekuasaan dalam bentuk negara-negara dengan dua karakteristik utama di wilayah ini, yakni negara-negara persungaian atau pesisir, seperti Kepulauan Indonesia, Semenanjung Malaya, dan Filipina serta negara-negara persawahan di dataran rendah di daratan Asia Tenggara, seperti Burma, Thailand, Kamboja, Laos, Vietnam, dan Jawa. Kegagalan Asia Tenggara menghadapi hegemoni kapitalisme dalam abad ke-9 menyebabkan pusat-pusat kekuasaan ini berubah posisi dari 'pusat' menjadi 'pinggiran' (Zuhdi, 2014). Wilayah Asia Tenggara menjadi penyedia sumber daya bagi negara-negara kolonial, sementara kemakmuran lebih banyak dinikmati oleh negara-negara kolonial itu. Keberlanjutan jaringan pelayaran di Asia Tenggara juga mengalami keterputusan, sehingga dunia bahari yang identik dengan dunia Melayu pun perlahan memudar.

Pada abad ke-19, laut menjadi wilayah persaingan antara kapitalisme Belanda dan Inggris, yang berakibat pada permasalahan batasbatas wilayah kolonial keduanya. Pemerintah Kolonial Belanda lebih khawatir tentang daerah perbatasannya dibandingkan Inggris karena kebijakan perdagangan Belanda yang cenderung monopolistik dan juga karena Belanda menghadapi perlawanan dari kaum pribumi di sepanjang perbatasan (Zuhdi, 2014). Persaingan ini kemudian melahirkan pembagian wilayah baru yang tegas mengenai wilayah perbatasan, tidak hanya sebagai wilayah perdagangan tapi juga wilayah budaya. Penguasaan Belanda dan Inggris atas wilayah Asia Tenggara telah berdampak pada memudarnya tradisi maritim yang menjadi ciri dari budaya Melayu.

Keruntuhan Majapahit dan munculnya Mataram (abad ke-16 sampai 19) makin mene- gaskan struktur kekuasaan yang memusat di keraton dan berorientasi ke pedalaman dengan didukung pertanian agraris (Zuhdi, 2014). Perubahan ini turut menggeser identitas kebaharian menjadi identitas agraris. Dikotomi ini tidak lagi sekedar menyangkut dimensi ruang, tapi juga budaya, sosial, dan politik, termasuk dalam pola pengelolaan sumber daya yang semakin mengarah pada pola konsentrik sehingga laut justru menjadi bagian luar dari wilayah kekuasaan.Sampai awal abad ke20, peran laut semakin lemah ketika kota dan industrialisasi perkebunan menjadi potensi eksploitasi yang menjanjikan bagi pemerintah kolonial. Kota-kota baru tumbuh dengan membelakangi air. Sungai dan laut menjadi tempat limbah atau pembuangan perkebunan. Permukiman penduduk di bantaran sungai dan tepi laut identik dengankondisi yang kumuh dan kotor. Masa kolonial merupakan mimpi buruk bagi maritim nusantara dan proses tersebut dilanjutkan setelah kemerdekaan, dengan strategi pembangunan yang justru makin meminggirkan potensi kelautan.

Dalam konsepsi nasionalisme sebagai konstruksi sosial, ada persoalan besar untuk membentuk nasionalisme dari identitas maritim karena keterputusan identitas tersebut. Meskipun demikian, ingatan tentang kejayaan kerajaankerajaan maritim masih tetap menghidupkan mimpi untuk mengembalikan identitas tersebut. Deklarasi Juanda pada 13 Desember 1957 yang menyatakan bahwa Indonesia adalah negara kepulauan yang terintegrasi menjadi salahsatu tonggak penting yang menunjukkan bahwa wacana negara maritim tidak pernah padam.

\section{REIMAJINASI INDONESIA SEBAGAI NEGARA MARITIM}

Wacana negara maritim yang kembali muncul di masa reformasi merupakan reaksi terhadap pelanggaran kedaulatan yang terjadi di wilayah laut Indonesia. Kasus-kasus penangkapan ikan secara ilegal, sengketa pulau-pulau terdepan, dan konflik perbatasan dengan negara tetangga menjadi pemicu kebangkitan nasionalisme demi mempertahankan harga diri bangsa dan negara. Di sisi lain, masyarakat yang bermukim di wilayah pesisir dan perbatasan laut juga menghadapi persoalan kemiskinan. Semua permasalahan ini sangat berbeda dengan ingatan kolektif tentang kejayaan laut dan budaya bahari 
yang pernah menjadi pusat kebudayaan di masa lampau.

Keterputusan identitas bahari menyebabkan laut dan pulau-pulau kecil dimarginalkan, antara lain tampak daripenyebutan 'pulau terluar' yang mengandung makna seolah-olah pulaupulau tersebut berada di luar wilayah Indonesia. Pandangan ini bertentangan dengan prinsip laut sebagai sistem yang mengintegrasikan pulaupulau. Tidak dapat dipungkiri bahwa secara geografis, ada kesulitan untuk dapat menjangkau semua pulau yang ada di wilayah terdepan dari batas teritorial Indonesia, tapi ketiadaan sarana transportasi yang menghubungkannya menjadi indikasi bagaimana persoalan ini ditangani. Alih-alih menjadi penghubung, laut kemudian menjadi pemisah dan penghambat kesejahteraan.

Kondisi laut di masa sekarang sangat berbeda dengan pada masa kejayaan kerajaankerajaan maritim di nusantara. Karena itu, bangkitnya kembali wacana negara maritim menjadi hal menarik karena kemunculannya didasari oleh penyebab yang berbeda dengan identitas di masa lampau. Jika di masa lampau identitas negara maritim muncul karena kejayaan di laut, seperti terungkap dalam semboyan Jalesveva Jayamahe, sekarang wacana negara maritim bangkit justru karena keterpurukan. Di masa lampau, identitas kejayaan ini menjadi simbol perlawanan terhadap kolonialisme dan imperialisme, sebaliknya di masa sekarang, kemiskinan dan keterpurukan menjadi simbol perlawanan terhadap kemiskinan.

Reimajinasi negara maritim Indonesia di masa kini dibangun di atas semangat perlawanan terhadap mode pengaturan lama yang memarginalkan laut. Pada ranah global, terjadi pergeseran konteks kekuasaan dalam hal hubungan perdagangan antarnegara yang kembali menempatkan Samudera Hindia dan Samudera Pasifik sebagai dua jalur pelayaran penting. Negara-negara kawasan Asia tumbuh sangat cepat, sementara perekonomian negaranegara Eropa dan Amerika Serikat sedang mengalami kejenuhan. Situasi ini mampu semakin menggeser arus perdagangan dari dan menuju Asia, yang sebagian besar melalui wilayah laut di Indonesia. Seiring potensi peningkatan volume perdagangan yang pesat dengan diberlakukannya pasar bebas dan potensi semakin meningkatnya produktivitas perekonomian Cina, maka hal ini menjadi sebagai sebuah tantangan pengembangan wilayah laut Indonesia sebagai Poros Maritim Dunia.

Dalam Focus Group Discussion APEC yang diselenggarakan April 2013, konektivitas maritim menjadi agenda penting yang dibahas. Demikian pula ASEAN telah mengembangkan rencana sistem transportasi laut untuk menghubungkan rute-rute pelayaran di perairan Asia Tenggara sebagai bagian dari rencana induk ASEAN Connectivity. Tidak hanya terkait dengan kepentingan ekonomi, isu keamanan juga menjadi hal penting yang turut menguatkan kembalinya wacana negara maritim. Apalagi jika dikaitkan dengan perubahan global yang kembali memandang penting jalur perdagangan melalui wilayah perairan, maka isu keamanan menjadi penting bagi Indonesia untuk mempertahankan kedaulatannya di laut. Meningkatnya aktivitas militer di perairan Samudera Hindia dan Samudera Pasifik serta konflik di Laut Cina Selatan terkait dengan klaim Cina atas Kepulauan Natuna menjadi isu-isu penting bagi keamanan maritim Indonesia. Tidak hanya menegaskan tentang lemahnya infrastruktur pertahanan maritim Indonesia, isu-isu tersebut juga membangkitkan kesadaran bahwa ada anomali dalam kebijakan pertahanan Indonesia yang selama ini terlampau berorientasi pada daratan, padahal bentukwilayah Indonesia adalah negara kepulauan.

Perubahan yang terjadi di ranah global ini memberi peluang bagi reimajinasi nasionalisme maritim, yang dikonstruksi dari kepentingan ekonomi dan keamanan untuk melawan kemiskinan dan marginalisasi laut. Imajinasi yang muncul dari kesadaran bahwa Indonesia memerlukan armada yang kuat untuk melawan ancaman-ancaman eksternal dan mengamankan wilayah pesisir, pulau-pulau, kawasan strategis, pusat-pusat perdagangan antarpulau, dan Zona Ekonomi Eksklusif yang merupakan aset Indonesia. Mempertahankan aset-aset ini tidak bisa sekedar dengan pendekatan keamanan, tapi juga dengan menghadirkan negara di sana. Nasionalisme, dengan begitu, dibuktikan melalui kehadiran negara untuk menjamin keamanan wilayah perairan sekaligus mensejahterakan warga masyarakat yang ada di sana. 
GAGASAN POROS MARITIM DUNIA: MEMADUKAN KESEJAHTERAAN DAN KEAMANAN

Salahsatu kebijakan negara maritim yang dirumuskan pemerintahan Jokowi adalah menjadikan Indonesia sebagai poros maritim dunia yang menghubungkan jalur transportasi antarpulau dan meningkatkan daya dukung dari pelabuhan-pelabuhan yang ada di wilayahwilayah pesisir Indonesia. Gagasan poros maritim dunia ingin menjadikan Indonesia sebagai kekuatan maritim yang diperhitungkan di antara dua benua (Asia dan Australia) serta antara dua samudra (Hindia dan Pasifik). Samudra Hindia akan berada pada posisi geostrategis yang penting, sehingga harus dijamin agar tidak menjadi arena pertarungan di antara negaranegara di sekitarnya. Indonesia memiliki wilayah perbatasan maritim sepanjang hampir 1300 km di Samudra Hindia, berbatasan dengan Australia, India, Malaysia, dan Thailand. Selain itu, Indonesia juga memiliki Zone Ekonomi Eksklusif sejauh 1,5 juta km2 di bagian timur Samudra Hindia. Dengan kondisi ini, Samudra Hindia telah menjadi kawasan yang penting bagi pertumbuhan ekonomi Indonesia, sekaligus juga menjadi sumber kerentanan dalam hal keamanan bagi Indonesia. Tapi, di sisi lain juga berpeluang untuk mengembangkan kerjasama regional yang saling menguntungkan.

Gagasan poros maritim dunia merupakan respon Indonesia terhadap perubahan ekonomi dan konstelasi kekuasaan yang terjadi di ranah global. Pergeseran pusat perekonomian dunia ke kawasan Asia Pasifik yang mayoritas negara-negara di dalamnya adalah negara kepulauan, telah menghasilkan peta pertarungan kepentingan baru di antara negara-negara di kawasan tersebut. Pertarungan ini bukan lagi terjadi di daratan (continent), tetapi berpindah ke persaingan dalam penguasaan laut atau samudera. Fenomena sengketa maritim di Laut China Selatan merupakan bukti dari pertarungan kepentingan tersebut.

Di sisi lain, hadirnya kepentingan-kepentingan negara besar di kawasan Asia Pasifik juga mencerminkan pertarungan ideologis untuk memperebutkan sumber daya alam di negara-negara sekitar kawasan Asia Pasifik, termasuk Indonesia. Secara eksplisit berarti pertarungan ideologis antara kekuatan neoliberal AS, dengan Kapitalisme Cina dan Rusia dalam berebut pengaruh untuk menguasai sumber daya alam. Dengan demikian konflik Laut China Selatan juga menjadi cerminan pertarungan kepentingan antara Cina dan AS yang berpeluang melebar ke kawasan dan negaranegara sekitarnya.

Dinamika politik dan ekonomi internasional di kawasan Asia Pasifik ini merupakan momentum yang jika dimanfaatkan dengan cermat dan tepat dapat memberikan peluang yang baik bagi Indonesia. Berbasis pada potensi dan tantangan yang dimiliki Indonesia sebagai konsekuensi dari perubahan yang terjadi di ranah global, kebijakan pembangunan diarahkan menuju pengembangan perekonomian maritim yang terintegrasi dengan pembangunan wilayah darat. Melalui integrasi ini, pembangunan maritim pada akhirnya akan membantu peningkatan efisiensi dan efektivitas pada aktivitas perekonomian yang berkembang di wilayah darat.

Melalui gagasan poros maritim dunia, imajinasi baru Indonesia sebagai negara maritim ini dipadukan juga dengan kepentingan ekonomi, memunculkan konstruksi makna baru tentang nasionalisme sebagai jatidiri bangsa yang dikaitkan dengan kesejahteraan. Sebagai negara yang terdiri atas 17 ribu pulau, bangsa Indonesia harus menyadari bahwa identitas, kemakmuran, dan masa depannya sangat ditentukan oleh pengelolaan sumber daya kelautan yang dimilikinya. Hal ini dilakukan melalui strategi, yakni membangun kedaulatan pangan melalui pengembangan industri perikanan, memprioritaskan pengembangan infrastruktur dan konektivitas maritim, dengan membangun jalan tol laut, pelabuhan laut dalam (deep seaport), logistik, industri perkapalan, dan pariwisata maritim, serta strategi keamanan-pertahanan yang dilakukan dengan melaksanakan diplomasi maritim untuk menghilangkan sumber konflik di laut, seperti pencurian ikan, pelanggaran kedaulatan, sengketa wilayah, perompakan, dan pencemaran laut serta membangun kekuatan pertahanan maritim untuk menjaga keselamatan pelayaran dan keamanan maritim.

Tujuan utama dari realisasi Indonesia sebagai Poros Maritim Dunia adalah kesejahteraan rakyat melalui pembangunan infrastruktur maritim seperti pelabuhan, menghidupkan lalu lintas laut sehingga distribusi barang dapat sampai ke pelosok dengan harga yang seimbang, 
memperoleh sebesar-besarnya manfaat dari laut tidak hanya bagi nelayan tetapi juga bagi seluruh rakyat Indonesia. Dengan mempertimbangkan bahwa 90\% transaksiperekonomian dunia terjadi di atas laut, yang mana $40 \%$ dari angka tersebut melalui Indonesia, tapi hanya 40\% transportasi laut domestik dilakukan oleh orang Indonesia, dengan sekitar 5\% dari ekspor dilakukan oleh kapal domestik, sedangkan sisanya yaitu 95\% oleh kapal asing (Pratama, 2015). Dengan kondisi seperti ini, menjadikan Indonesia sebagai negara maritim perlu diimbangi dengan kebijakan-kebijakan pendukung terkait dengan pengelolaan wilayah laut dan perbatasan Indonesia. Reimajinasi sebagai negara maritim mengharuskan perubahan cara pandang untuk menjadikan laut sebagai beranda depan, sehingga kebanggaan sebagai negara maritim tidak lagi didasarkan pada romantisme kejayaan masa lampau, tapi oleh kesejahteraan yang dinikmati oleh warga negara yang bermukim di pulau-pulau terdepan dan perbatasan Indonesia.

\section{PENUTUP}

Nasionalisme adalah konstruksi yang dinamis sebagai respon terhadap tantangan zaman. Demikian pula dengan bangkitnya identitas negara maritim, sesungguhnya merupakan konstruksi nasionalisme baru yang memadukan antara mimpi kedaulatan teritorial dan kesejahteraan. Ketertinggalan pembangunan daerah-daerah di wilayah perairan justru menjadi pemicu bangkitnya nasionalisme maritim ketika berhadapan dengan ancaman perdagangan bebas dan perebutan penguasaan sumber daya alam di perairan lepas Indonesia. Perwujudan nasionalisme maritim melalui gagasan poros maritim dunia, di tengah dinamika kawasan Asia Pasifik saat ini, menjanjikan peluang bagi Indonesia untuk dapat bangkit sebagai bangsa yang maju, kuat, dan memiliki posisi tawar di kawasan sebagai bangsa maritim. Di sisi lain, jika pemerintah tidak mewujudkan gagasan ini dengan kebijakan yang komprehensif, maka momentum ini akan menjadi ancaman karena wilayah laut Indonesia akan menjadi ajang perebutan penguasaan sumber daya alam oleh negara-negara besar. Lebih jauh lagi dalam ranah identitas dan ideologis, identitas bangsa Indonesia juga turut menghadapi tantangan. Identitas sebagai negara maritim memerlukan perubahan mendasar, yang mencakup modernisasi armada laut, alokasi anggaran, peningkatan kapasitas teknis dalam hal pengelolaan laut, dan seterusnya. Hal ini diperlukan untuk menjamin bahwa kedaulatan bahari sungguh-sungguh dapat diwujudkan melalui kehadiran negara di wilayah terdepan ini. Demikian pula, dalam hal perwujudan kesejahteraan, mimpi negara maritim perlu diimbangi dengan pembangunan infrastruktur lokal dan teknologi yang dapat memaksimalkan potensi sumber daya yang tersedia, khususnya untuk menarik minat investasi di wilayah perairan Indonesia. Untuk mewujudkan ini semua, diperlukan dukungan politik dari semua pihak, sehingga identitas sebagai negara maritim tidak sekedar menjadi wacana tapi mimpi kolektif bangsa Indonesia.

\section{DAFTAR PUSTAKA}

Anonim. 2013. Master Plan on ASEAN Connectivity. http:/www.mfa.go.th/ asean/contents/files/asean-mediacenter-20121203-182010-779067.pdf. (diakses 6 Maret 2015).

Fitriyanti, A. 2013. "News Focus - Big Agenda, Maritime Infrastructure Towards Indonesia, APEC Connectivity". Antara News. 9 April. http://www.antaranews. com/en/news/88298/news-focus-big-agenda-maritime-infrastructuretowards-indonesia-apec-connectivity. (diakses 6 Maret 2015).

Hall, Kenneth R. 1985. Maritime Trade and State Development in Early Southeast Asia. Honolulu: University of Hawaii Press.

Kahin, George. Mc.T. 1952. Nationalism and Revolution in Indonesia. Ithaca, NY: Cornell University Press.

Philpott, Simon. 2003. Meruntuhkan Indonesia: Politik Postkolonial dan Otoritarianisme. Terj. Nuruddin Mhd. Ali, Uzair Fauzan. Yogyakarta: LKiS.

Pratama, Tide Aji. 2015. "Kebijakan Poros Maritim Dunia di tengah Dinamika Asia Pasifik saat ini". https://www.academia. edu/10062323/Kebijakan_Poros_ Maritim_Dunia_Di_Tengah_Dinamika_ Asia_Pasifik. (diakses 6 Maret 2015). 
Santoso, Purwo. 2001. "Merajut Kohesi Nasional:Etno-nasionalismedanOtonomi Daerah dalam Proses Demokratisasi". Jurnal Sosial Politik Vol. 4(3): 265-288.
Reid, Anthony. 2004. Sejarah Modern Awal Asia Tenggara. Terj. Sori Siregar, Hasif Amini, dan Doris Setiawan. Jakarta: LP3ES.

Zuhdi, Susanto. 2014. Nasionalisme, Laut, dan Sejarah. Depok: Komunitas Bambu. 